\title{
Optimal Concentrations of Silicon Enhance the Growth of Soybean (Glycine max L.) Cultivars by Improving Nodulation, Root System Architecture, and Soil Biological Properties
}

Mahdieh Shamshiripour

University of Tehran

Babak Motesharezadeh

University of Tehran

Hadi Asadi Rahmani

Soil and Water Research Institute

Hossein Ali Alikhani

University of Tehran

Hassan Etesami ( $\nabla$ hassanetesami@ut.ac.ir)

University of Tehran https://orcid.org/0000-0002-5225-7209

\section{Research Article}

Keywords: Bradyrhizobial strains, Nitrogen uptake, Nodule, Root morphology, Silicate-solubilizing bacteria

Posted Date: June 21st, 2021

DOI: https://doi.org/10.21203/rs.3.rs-639171/v1

License: (c) (i) This work is licensed under a Creative Commons Attribution 4.0 International License. Read Full License

Version of Record: A version of this preprint was published at Silicon on August 17th, 2021. See the published version at https://doi.org/10.1007/s12633-021-01273-3. 


\section{Abstract}

Today, the beneficial role of silicon (Si) in increasing the growth and yield of monocotyledons has been proven. But the effect of this useful element on dicotyledonous plants such as legumes has been less studied. In addition, the effect of Si on the development of roots and on nodulation in soybeans is still an unexplored research area. In this study, the effect of different levels of $\mathrm{Si}(0,100,200,400,600$ and 800 mg Si kg-1 soil) from potassium silicate source on some soil biological properties, root morphological characteristics and nutritional responses of four soybean cultivars (cv., Katool, Sari, Saland and Saman with specific growth groups and identity cards) was studied under greenhouse conditions. The results showed that Si application in all cultivars caused a significant increase in shoot dry weight, root length and increased $\mathrm{Si}$ and nitrogen uptake in soybean shoots. Also, the application of $\mathrm{Si}$ increased nodulation in four soybean cultivars compared to the control treatment. The observed different responses to $\mathrm{Si}$ addition were cultivar-specific, probably related with the various Si efficiency strategies developed by these four soybean cultivars. The responses of soybeans to the application of Si levels were finally positive up to the level of $600 \mathrm{mg} \mathrm{Si} \mathrm{kg-1}$ and at higher levels there were no any increase (or an inhibitory effect) in nutritional responses and other growth characteristics compared to control. Silicon also caused a significant increase in total bacterial population, silicate-solubilizing bacteria population, microbial biomass, and microbial respiration rate of the soil under cultivation of different soybean cultivars. In this study, the improved growth (shoot dry weight) of soybean cultivars associated with Si treatment was highly correlated with nodulation, root morphological traits, and soil biological properties. In general, our findings suggest that optimal concentrations of Si can be a promising way to improve the production of soybean cultivars.

\section{Introduction}

Silicon (Si) exists in nature in combination with oxygen in the form of silicate and in terms of abundance, Si makes up about $28 \%$ of the Earth's crust [1]. Therefore, due to its abundance in soil, Si has been considered by many scientists in terms of its effect on plant nutrition, soil fertility and alleviation of environmental stresses. A lot of evidence shows that Si has been effective in improving the genetic, morphological and physiological characteristics of the plant as well as alleviating biotic and abiotic stresses in various plants as in some cases it is considered as a "quasi-essential" nutrient [2,3]. In general, the use of Si has had positive effects on the growth and yield of several crops, especially those that accumulate $\mathrm{Si}$, such as rice (Oryza sativa L.), sugarcane (Saccharum officinarum L.), corn (Zea mays L.), sorghum (Sorghum bicolor L.), and wheat (Triticum aestivum L.) [3, 4]. Recent research shows that in addition to monocotyledons plants, dicotyledonous plants also have silicon transport genes in their roots. Therefore, silicon can be effective in stimulating the physiological responses of these plants [57]. However, the influence of Si on the development of leguminous plants is little known [7].

Based on the studies published in 1999 to 2019, there were a total of 641 reports on the effects of Si on the morphological and physio-biochemical properties of 159 plant species, a small percentage of which (7\%) are legumes [7]. This is because silicon was considered an unnecessary element for legumes. 
Recent reports, however, have shown that some legumes can accumulate relatively high concentrations of $\mathrm{Si}$ in their leaf tissues [7]. It is known that the application of $\mathrm{Si}$ increases the availability of this element in the soil and $\mathrm{Si}$ can be taken up by each plant [2].

Soybean (Glycine max L.) is a grain legume of the family Fabaceae and a strategic crop that needs more attention to its production in the world due to its nutritional value [8]. Given the importance of this plant in agriculture and food supply (future food security), the use of management strategies and methods that can solve production problems and ultimately optimize soybean yield are very important as the agricultural goals of soybean. Based on a few studies on legume plants, Si can have multiple effects on improving soybean growth and yield [9]. In addition to increasing soybean resistance to abiotic and biotic stresses [10-12], Si has been reported to increase seed germination and promote the growth and yield of the soybean $[13,14]$. For example, in a study, Pascual, Echevarria [15] investigated the effect of silicon application on soybeans under zinc deficiency conditions. Their results showed that application of 0.5 $\mathrm{mM} \mathrm{Si}$ in nutrient solution led to increased plant growth, zinc and Si content in leaves and more zinc storage in root apoplasts.

One of the important features of legumes is their role in biological nitrogen fixation by promoting symbiotic association with nitrogen $\left(\mathrm{N}_{2}\right)$ fixing bacteria $[7,16]$. Recent research shows that $\mathrm{Si}$ can have a positive effect on increasing the activity of $\mathrm{N}_{2}$-fixing bacteria, the numbers of bacteroids, biological nitrogen fixation, nodulation, the synthesis of amino acids, and grain protein in the legumes $[7,9,16,17]$. It has been known that Si improves nodule size and number in legumes by increasing root growth and lateral root development and growth (the total number of secondary roots) [18] because of the accumulation of abscisic acid in the roots [19-21]. Accordingly, Si can be considered as an essential element to improve nitrogen fixation efficiency in soybean [22]. There is evidence that soybean is considered a Si non-accumulating legume, but it has a very good capacity for transporting absorbed $\mathrm{Si}$, as monosilicic acid or orthosilicic acid $\left(\mathrm{H}_{4} \mathrm{SiO}_{4}\right)$, from root to shoot, especially leaf $[23,24]$.

The exact mechanism of action by which Si increases the efficiency of the nitrogen fixation in legumes is not yet known. It is known that root morphology and nodule formation in the roots (e.g., nodules are developed in the roots via bacterial infections) determine the growth and development of shoots in legume plants [16]. However, the effects of Si on nodulation and root morphology in legumes including soybean remain unknown $[9,25,26]$.

It has been reported that $\mathrm{Si}$ application-induced increase of the growth of root and nitrogen fixed from the nodules depends on the concentrations of Si, growing substrates, and types of Si [24], various plant species (various cultivars), and ability of the plants (e.g., legumes) to absorb this element [27]. For example, in a study [28], the applied Si level was not be adequate to be influential to lateral root formation in soybean.

Roots as an indispensable organ for water acquisition and nutrient absorption throughout a plant's life [29] take part in the generation of various organic acids, amino acids, and hormones [30]. These root 
exudates in turn stimulate bacterial proliferation, microbial activity (soil respiration rate, soil microbial biomass, etc.) and communities (e.g., silicate and phosphate solubilizing bacteria and indole-3-acetic acid-producing bacteria, etc.) [31]. Soil microbial community can participate in nutrient cycling (e.g., N, P, $\mathrm{Si}$, etc.) through interaction with the root of plants [32].

Keeping this in mind, the present study was aimed to evaluate the effect of different levels of $\operatorname{Si}(0,100$, $200,400,600$ and $800 \mathrm{mg} \mathrm{Si} \mathrm{kg}^{-1}$ soil) from potassium silicate source on morphological characteristics and nutritional responses of four soybean cultivars (cv., Katool, Sari, Saland, and Saman with specific growth groups and identity cards) and some soil biological properties under greenhouse conditions. We hypothesized that Si increases soybean growth (shoot dry weight) by (i) increasing nodulation (e.g., biological nitrogen fixation and as a result an increase in plant $\mathrm{N}$ content) and (ii) improving soybean root system architecture (e.g., an increase in water acquisition and nutrient absorption and an increase in the number of potential sites for infection by bradyrhizobial invasion) and soil microbial activity (e.g., improving nutrient cycling) due to root growth-induced increase in root exudates. Understanding the role of Si improving root morphological traits and nodulation (the legume-rhizobium relationship) and investigating the optimal concentration of Si for nodule formation and each of the root morphological traits help predict the growth and development of legumes including soybean.

\section{Materials And Methods}

\subsection{Soil sampling and analysis}

Due to the need for a soil with a very low population of rhizobial bacteria, a low percentage of nitrogen, and a low available Si (54 mg kg-1, critical limit for $\mathrm{Si}$ ) in this experiment, a soil (a depth of 0-30 cm) under perennial fallow was sampled from the research farm of the Soil and Water Research Institute, Karaj, Iran. The samples were placed into nylon bags, and transported to the laboratory for soil analysis and use in pots. Soil samples were air-dried, passed $2 \mathrm{~mm}$ sieve and analyzed according to standardized procedures. The soil had a loam texture with $32 \%$ sand, $44 \%$ silt, and $24 \%$ clay; total $\mathrm{N}, 0.08 \%$; organic C, $0.43 \%$; $\mathrm{pH}, 7.2$; electrical conductivity, $1.89 \mathrm{dS} \mathrm{m}^{-1}$; saturated moisture, $30.74 \%$; available P, $9.3 \mathrm{mg} \mathrm{kg}^{-1}$; available K, $186 \mathrm{mg} \mathrm{kg}^{-1}$; available $\mathrm{Fe}, 4.06 \mathrm{mg} \mathrm{kg}^{-1}$; available Si, $23.14 \mathrm{mg} \mathrm{kg}-1$; and calcium carbonate equivalent, $10.6 \%$.

\subsection{Selection of soybean cultivars and effective symbiotic bacterium}

In this study, four soybean cultivars (cv., Katool, Sari, Saland and Saman with specific growth groups and identity cards) were selected among 11 soybean cultivars. In addition, an effective bacterial strain symbiotic to these cultivars, strain RS-157, was selected among 55 bradyrhizobial strains. Out of 55 bradyrhizobial strains, 36 strains had been isolated from soybean cultivars grown in Iran and 19 strains had been isolated from soybean cultivars grown in Brazil, Italy, Australia, USA and Russia. All these bacterial strains were obtained from the microbial collection of the Soil and Water Research Institute, Karaj, Iran. The choice was based on having the highest symbiotic efficiency (SE). The SE of 
Bradyrhizobium japonicum RS-157 (CCSM01275), which was obtained from All-Russia Institute for Agricultural Microbiology, with the cultivars of Katool, Sari, Saland and Saman was 296, 281, 295, and $168 \%$.

\subsection{Experimental set-up and treatments}

In order to investigate the effect of different levels of Si on growth parameters, some properties related to nitrogen fixation of four selected soybean cultivars (cv., Katool, Sari, Saland and Saman) and some soil biological properties, an experiment was conducted in a completely randomized design in factorial arrangement in three replications under greenhouse conditions. Experimental treatments included: Cultivar factor at four levels (i) Katool; (ii) Sari; (iii) Saland; and (iv) Saman and Si factor from a source of potassium silicate at six levels (I) $0 \mathrm{mg} \mathrm{Si} \mathrm{kg}^{-1}$ soil (control); (ii) $100 \mathrm{mg} \mathrm{Si} \mathrm{kg}^{-1}$ soil; (iii) $200 \mathrm{mg} \mathrm{Si} \mathrm{kg}^{-1}$ soil; (iv) $400 \mathrm{mg} \mathrm{Si} \mathrm{kg}^{-1}$ soil; (v) $600 \mathrm{mg} \mathrm{Si} \mathrm{kg}^{-1}$ soil; and (vi) $800 \mathrm{mg} \mathrm{Si} \mathrm{kg}^{-1}$ soil. Varied Si concentrations to obtain the optimized concentration of $\mathrm{Si}$ in this study were applied in this study as it is known that various plant species have indicated various requirements for Si addition [2]. In addition, the Si concentration used here was equivalent to those extensively applied in other studies [33-35].

Each experimental unit consisted of $4 \mathrm{~kg}$-plastic pots $(15 \mathrm{~cm}$ high and $17 \mathrm{~cm}$ in diameter) containing $3 \mathrm{~kg}$ of soil sieved passing through a $4 \mathrm{~mm}$ mesh. The amount of $\mathrm{Si}$ treatments was added to the potting soil about 4 weeks before planting. The amount of potassium added to the respective pots by applying potassium sulfate was calculated and added to the other pots from the source of potassium sulfate. Also, based on the results of soil test, nutrient deficiency was identified and supplied. The pots were incubated in greenhouse conditions for four weeks. The seeds of the cultivars were obtained from the Seed and Plant Breeding Research Institute, Karaj, Iran. The seeds were surface-disinfected with 96\% alcohol and $5 \%$ sodium hypochlorite solution for $1 \mathrm{~min}$; and then washed three times with sterilized distilled water. The seeds were germinated on $0.8 \%$ agar-water plates in the dark at $28{ }^{\circ} \mathrm{C}$ for 48 . Healthy germinated same-sized seeds were planted in each pot (five germinated seeds were planted in each pot and thinned to three uniform seedlings), then inoculated with $1 \mathrm{~mL}$ of $B$. japonicum RS- 157 suspension $\left(5 \times 10^{8}\right.$ cells $\left.\mathrm{mL}^{-1}\right)$, the bacterial cells grown in yeast extract mannitol broth at $28^{\circ} \mathrm{C}$ when turbidity was 0.5 at exponential growth phase. Greenhouse temperature was set at $25^{\circ} \mathrm{C}$, light intensity at 20,000 lux and relative humidity at $70 \%$. In the first week of the growing period, $20 \mathrm{~kg} \mathrm{ha}^{-1}$ ammonium nitrate fertilizer was used as a starter. The plants were irrigated with distilled water as required.

\subsubsection{Measurements}

After about 8 weeks of growth period (before entering the reproductive period), the plants were harvested and shoot dry weight (SDW), root dry weight (RDW), root volume, root length, root area, number of nodules in the root, and nodule score [36] were measured. The nodule score indicates the distribution and number of effective nodules (on basis of nodule size and internal pigmentation) on the roots of soybean cultivars. Nitrogen concentration in shoots was measured by Kjeldahl method [37]. To measure Si in shoot, colorimetric method was used based on the formation of a blue reduced amino molybdate 
complex, after which the $\mathrm{Si}$ concentration was measured by spectrophotometer at $820 \mathrm{~nm}$ [38]. Shoot $\mathrm{Si}$ uptake and shoot $\mathrm{N}$ uptake were calculated by multiplying shoot $\mathrm{Si}$ concentration by SDW and multiplying shoot $\mathrm{N}$ concentration by SDW, respectively. Also, some soil microbial properties such as soil microbial biomass (using fumigation-extraction method [39]), soil microbial respiration rate [40], total soil bacterial population (using the dilution-plate method (CFU g-1 soil) [41]), and silicate solubilizing bacterial population [42] were measured.

\subsection{Statistical analysis}

All data were subjected to two-way analysis of variance (ANOVA) using SAS v.9.1 (SAS Institute Incl, Cary, NC) statistical analysis software. The assumptions for ANOVA were checked using Shapiro-Wilk test 238for normality, and Levenés test for homogeneity of variances. Tukey's multiple comparison test ( $\mathrm{P} \leq$ 0.05) using SPSS package (version 24.0) (Inc, 2016) was performed to find means that are significantly different from each other. The Pearson test (two-tailed) at $p \leq 0.01$ was used for analyzing correlation among gauged parameters.

\section{Results}

\subsection{Effect of Si levels on morphological traits of soybean cultivars}

The results showed that shoot dry weight (SDW) in all cultivars increased (e.g., 23.8, 25.4, 18.9, and $29.1 \%$ for Katool, Saman, Sari, and Saland, respectively, compared to control) with increasing the amount of Si from 0 to $600 \mathrm{mg} \mathrm{kg}^{-1}$ soil; although this increase did not have an upward trend in various cultivars (Fig. 1). But at the level of $800 \mathrm{mg} \mathrm{Si} \mathrm{kg} \mathrm{soil,} \mathrm{a} \mathrm{decrease} \mathrm{in} \mathrm{SDW} \mathrm{in} \mathrm{all} \mathrm{cultivars} \mathrm{compared} \mathrm{to} \mathrm{control} \mathrm{was}$ observed (Fig. 1). The highest SDW was related to the treatment of $100 \mathrm{mg} \mathrm{Si} \mathrm{kg}^{-1}$ in Saman cultivar. The cultivars that were most affected by the Si treatments were Katool and Saman cultivars.

Silicon treatments had also a positive effect on increasing root length in different cultivars, which was different in different cultivars. Katool, Saman and Sari cultivars showed the highest increase in root length at the level of $600 \mathrm{mg} \mathrm{Si} \mathrm{kg}^{-1}$, while the highest increase in root length in Saland cultivar was related to the treatment of $200 \mathrm{mg} \mathrm{Si} \mathrm{kg}^{-1}$ and then a decreasing trend was observed (Fig. 2). Si-mediated increase in root length was different in different cultivars, indicating the different responses of cultivars to silicon levels.

According to Fig. S1A, B, and C, with increasing Si levels, root dry weight, volume and area also increased. But this increase was different in different cultivars, indicating the different responses of cultivars to silicon levels.

The results showed that $\mathrm{Si}$ application had a positive effect on root nodulation (Fig. 3). Application of Si increased the number of nodules (Fig. 3) and the nodule score in all cultivars (Fig. S1D). However, at level of $800 \mathrm{mg} \mathrm{Si} \mathrm{kg}^{-1}$, a decrease in the number of nodules was recorded. Si-mediated increase in the number of nodules was visible up to the level of $600 \mathrm{mg} \mathrm{Si} \mathrm{kg}^{-1}$. But the trend of changes shows that in the 
treatment of $800 \mathrm{mg} \mathrm{Si} \mathrm{kg}^{-1}$, the number of nodules decreased. The highest increase in the number of nodules was also related to Saman cultivar at level of $600 \mathrm{mg} \mathrm{Si} \mathrm{kg}^{-1}$. (Fig. 3)

\subsection{Effect of Si levels on shoot Si and N uptake of soybean cultivars}

The results of interactions between soybean cultivars and Si levels on shoot Si (Fig. 4) and N (Fig. 5) uptake showed an increase in the amount of $\mathrm{Si}$ and $\mathrm{N}$ taken up by soybean cultivars compared to the control treatment, which was different in various cultivars. However, with increasing the amount of Si to the level of $800 \mathrm{mg} \mathrm{kg}^{-1}$, a decrease in the amount of absorbed Si and $\mathrm{N}$ was observed (Fig. 4 and 5). The highest amount of absorbed Si was related to the treatment of $600 \mathrm{mg} \mathrm{Si} \mathrm{kg}^{-1}$ in Katool cultivar. Also, the trend of changes shows that in the treatment of $800 \mathrm{mg} \mathrm{Si} \mathrm{kg}^{-1}$, the amount of absorbed Si decreased so that it was not much different from the control treatment (without the use of $\mathrm{Si}$ ). The cultivars that were most affected by the Si treatments were Katool and Saland cultivars. The highest amount of taken up N by soybean cultivars was related to the treatment of $400 \mathrm{mg} \mathrm{Si} \mathrm{kg}^{-1}$ in Katool cultivar. The trend of changes shows that in the treatment of $800 \mathrm{mg} \mathrm{Si} \mathrm{kg}^{-1}$, the amount of taken up $\mathrm{N}$ decreased.

\subsection{Effect of Si levels on some soil biological properties}

The results of the interaction effects of soybean cultivars and Si levels showed an increase in soil bacterial population (Fig. 6A). The application of Si levels also increased the population of silicatesolubilizing bacteria up to the level of $600 \mathrm{mg} \mathrm{Si} \mathrm{kg}^{-1}$. But at the level of $800 \mathrm{mg} \mathrm{Si} \mathrm{kg}^{-1}$, a significant reduction in the population of this group of bacteria compared to other levels of Si (except for level of 200 $\mathrm{mg} \mathrm{Si} \mathrm{kg}{ }^{-1}$ ) was observed. The results of the interaction effects of soybean cultivars and Si levels also showed an increase in soil microbial respiration rate (Fig. 7A). Compared to control, all Si levels significantly $(P<0.05)$ increased soil microbial biomass, although there were no significant differences between these levels (Fig. 7B). The trend of changes in soil biological properties in soil under cultivation of different soybean cultivars in the presence of different levels of $\mathrm{Si}$ is shown in Fig. 8. For example, graph a in Fig. 8A, B, C, and D shows that as the level of Si increased, the population of total bacteria and silicate-solubilizing bacteria, soil microbial respiration, and soil microbial biomass in the soil increased. The highest amount in the total bacteria population, soil microbial respiration, soil microbial biomass, and silicate-solubilizing bacteria population was related to the treatment of $600 \mathrm{mg} \mathrm{Si} \mathrm{kg}^{-1}$ in Katool cultivar, Saland cultivar, Sari cultivar, and Saland cultivar, respectively (Fig. 8).

\subsection{Correlation analysis}

To analyze correlation among measured parameters, the Pearson test (two-tailed) at $\mathrm{P} \leq 0.01$ was used (data not shown). There was a significant correlation between shoot Si uptake and number of nodules $\left(\mathrm{r}^{2}\right.$ $=0.46, \mathrm{P}<0.01)$ and between shoot Si uptake and nodule score $\left(r^{2}=0.42, \mathrm{P}<0.01\right)$. There was also a 
significant correlation $\left(r^{2}=0.75, P<0.01\right)$ between nodule score and number of nodules. Three-

dimensional graph of these three parameters (Fig. 9A) also shows that with increasing Si level, the nodule score and number of nodules also increased. There was a significant correlation between shoot Si uptake and shoot dry weight $\left(r^{2}=0.72, P<0.01\right)$ and between shoot dry weight and nodule score $\left(r^{2}=0.48, P<\right.$ 0.01). According to Fig. 9B, with increasing shoot Si uptake, the nodule score also increased and as a result, the plant dry weight increased. There was a significant correlation between shoot Si uptake and shoot $\mathrm{N}$ uptake $\left(r^{2}=0.73, \mathrm{P}<0.01\right)$ and between shoot $\mathrm{N}$ uptake and shoot dry weight $\left(r^{2}=0.72, \mathrm{P}<\right.$ 0.01). With increasing Si level, shoot $\mathrm{N}$ uptake also increased and as a result, the shoot dry weight increased (Fig. 9C). There was a significant correlation between shoot $\mathrm{N}$ uptake and soil microbial biomass $\left(r^{2}=0.32, P<0.01\right)$ and between shoot $N$ uptake and root dry weight $\left(r^{2}=0.33, P<0.01\right)$. There was a significant correlation between soil respiration rate and soil microbial biomass $\left(r^{2}=0.28, P<0.05\right)$ and between soil respiration rate and nodule score $\left(r^{2}=0.41, P<0.01\right)$. There was a significant correlation between nodule score and soil microbial biomass $\left(r^{2}=0.56, P<0.05\right)$. According to Fig. 9D, with the increase of soil microbial biomass, soil respiration rate also increased and as a result, the nodule score increased. There was a significant correlation between total bacterial population and number of nodules $\left(r^{2}=0.49, P<0.05\right)$ and between total bacterial population and nodule score $\left(r^{2}=0.54, P<0.01\right)$. As total bacterial population increased, the number of nodules and nodule score also showed an increasing trend (Fig. 9E). There was a significant correlation between root dry weight and root volume $\left(r^{2}\right.$ $=0.56, \mathrm{P}<0.01)$ and between root dry weight and root area $\left(r^{2}=0.88, P<0.01\right)$. There was also a significant correlation $\left(r^{2}=0.87, P<0.01\right)$ between root area and root volume. According to Fig. $9 F$, with increasing root area and volume, the root dry weight also increased.

\section{Discussion}

Recent research has emphasized the role of Si in nodule formation in legumes, and according to this research, Si can be considered a vital element for improving rhizobia-legume symbiosis $[7,16]$. The results of the present study also showed that the soybean cultivars treated with various levels of Si had a high ability to form nodules and therefore higher concentrations of $\mathrm{N}$ in their shoots, for which there are some similar reports from other studies $[9,15,22]$. For example, in a study, foliar application of $2.0 \mathrm{mM} \mathrm{Si}$ as sodium metasilicate boosted nodulation and nodule size as compared to non-Si treated soybean [28].

In this study, the responses of different cultivars to various Si levels were different. In most parameters measured in four soybean cultivars, $800 \mathrm{mg} \mathrm{Si} \mathrm{kg}^{-1}$ level compared to other Si levels showed an inhibitory effect on these parameters compared to control. But at the optimal Si level (e.g., $600 \mathrm{mg} \mathrm{kg}^{-1}$ for Katool cultivar, $100 \mathrm{mg} \mathrm{kg}^{-1}$ for Saman and Saland cultivars, and $200 \mathrm{mg} \mathrm{kg}^{-1}$ for Sari cultivar), the shoot dry weight of these cultivars increased significantly compared to the control. Steiner, Zuffo [22] achieved similar (a two-fold increase in nodule number) results by applying Si up to $250 \mathrm{mg} \mathrm{kg}^{-1}$ in soybean. Mali, Aery [43] reported that the application of Si to a soil with available Si and nitrogen of $30 \mu \mathrm{g} \mathrm{g}^{-1}$ and $0.06 \%$, respectively, increased nodulation and nitrogen symbiotic efficiency in cowpea (Vigna unguiculata). 
According to these researchers, low concentrations of $\mathrm{Si}$ can be beneficial not only for nodule growth but also for cowpea plant growth. In the study of Mali, Aery [43], the high concentrations of $\mathrm{Si}$ also reduced root length and weight and the number of nodules of cowpea. The researchers attributed this decrease in measured parameters to the reduced leghemoglobin in legume nodules.

Due to the fact that different plants including legumes (e.g., soybean) absorb Si to varying degrees [44, 45] and also there is a direct correlation between their ability to take up $\mathrm{Si}$ and the benefits they draw from it, in this study, we also studied the ability of the soybean cultivars to absorb Si as little is known about these benefits for soybean cultivars. The soybean cultivars selected in this study showed different ability to absorb silicon, which is probably related with the different Si efficiency strategies developed by these cultivars. In a similar study, application of Si in soybean increased the amount of Si absorbed in the shoot [46]. The soybean cultivars used in this study could absorb Si in range of 2-4.3\% per dry matter (data not shown). This report suggests that the soybean cultivars can accumulate high levels of $\mathrm{Si}$ in their shoots, showing that Si can be well taken up from the soil. Hodson, White [44] also reported that soybeans can accumulate high concentrations of $\mathrm{Si}$ in their shoots by translocating $\mathrm{Si}$ freely from the roots to the tops [47]. Plants that absorb large amounts of silicon ( $>1 \%$ dry matter) often have Sitransferring genes that belong to nodulin twenty-six -like intrinsic proteins. These proteins contain genes that are responsible for transporting $\mathrm{Si}$ in the plant. These genes in soybean include the GmNIP2-1 and GmNIP2-2 genes [7]. In a previous study, some transporters for Si absorption from the soil as hyperaccumulating grasses in soybean was also reported [26].

According to previous studies $[7,16]$ and the hypotheses of this study, one of the ways that Si can improve the growth of legumes is by improving nitrogen fixation in nodes. In this study, it was found that $\mathrm{Si}$ improved nodule number and score in various cultivars at Si level $<800 \mathrm{mg} \mathrm{kg}^{-1}$. The results of increases in nodule number and score (e.g., nodule size and being effective) as a result of Si use are in agreement with similar findings from previous studies [9, 17, 22]. For example, Nelwamondo, Jaffer [48] found that at moderate concentrations, Si significantly boosted the number of symbiosomes and bacteroids in legumes. In study of Johnson, Hartley [49], Si application also improved nodule formation on root and production of foliar amino acids in alfalfa. A more recent study also announced that $\mathrm{Si}$ boosted nodule activity by the synthesis of leghaemoglobin, which is crucial to buffer $\mathrm{O}_{2}$ concentration in the nodule environment and to stabilize the $\mathrm{O}_{2}$-sensitive nitrogenase, in two various genotypes of pigeonpea (Cajanus cajan L.) [50].

Some of the mechanisms by which Si stimulates nodulation have been reported in a previous review study [16]. For example, Si stimulates nodulation by (i) changes in soil conditions; (ii) an increase in root growth and as a result establishing sites for the more colonization of rhizobial strains; (iii) an increase in abundance of bacteroides and symbioses along with the synthesis of compounds that increase the expression of nodulation genes [49]; (iv) changes in metabolism of phenolic compounds [51]; (v) synthesis of isoflavonoids released by the roots of the legumes [52], which act as chemical adsorbents for nitrogen-fixing bacteria [53] and induce boosted nodulation of leguminous plants [52]; (vi) an increase in absorption of micronutrients involved in the biological $\mathrm{N}_{2}$ fixation process such as molybdenum, 
cobalt, copper, and iron [54]; (vii) an decrease in metabolic cost of C compounds in the cell wall due to the replacement of Si with structural carbon; (viii) protecting nodules against environmental stresses [7]; and (ix) influencing the expression of nod genes, which affect the nodulation in leguminous plants [24].

Measuring plant $\mathrm{N}$ concentration (or plant dry matter) is one way to assess nitrogen fixation [55]. Our results clearly showed that shoot $\mathrm{N}$ uptake in the cultivars treated with Si levels lower than $800 \mathrm{mg} \mathrm{kg}^{-1}$ showed an increase compared to control. We also found significant correlations between shoot $\mathrm{N}$ uptake with number of nodules $\left(r^{2}=0.54, P<0.01\right)$, nodule score $\left(r^{2}=0.52, P<0.01\right)$, and shoot dry weight $\left(r^{2}=\right.$ $0.79, P<0.01$ ) (data not shown). Since nodules are known as an essential component of soybean roots to enable adequate the growth and development of shoots [56], it can be concluded that Si-mediated improvement of nodulation in roots of soybean cultivars can be the reason for increased shoot dry weigh of these cultivars. In previous studies, Si also had a positive effect on increasing nitrogen uptake in soybean shoots $[22,49]$. One question that may be asked is that $\mathrm{Si}$ may increase the uptake of $\mathrm{N}$ by soybean cultivars to the point that $\mathrm{N}$ is no longer restricted to growth of the cultivars. This may have a negative effect on the symbiosis of bradyrhizobial strain with the soybean cultivars. However, due to the high concentration of $\mathrm{N}$ required for the soybean and the relatively low concentration of $\mathrm{N}$ in the soil used in pots, this is unlikely. In a recent study, it was also reported that Si had no effect on $\mathrm{N}$ uptake by wheat [57].

Another hypothesis in this study was that $\mathrm{Si}$ application is responsible for improving root morphological traits (e.g., root dry weight, length, area, and volume) of soybean cultivars and as a result increasing the number of potential sites for infection by bradyrhizobial invasion. In the present study, root dry weight was significantly correlated with nodule number $\left(r^{2}=0.50, P<0.01\right)$. Furthermore, $S i$ also improved root morphological traits of soybean cultivars measured in this study. The results of increases in root morphological traits as a result of Si use are in agreement with similar findings from previous studies [9, 18]. In a previous study [28], the Si application was also highly correlated with a higher root angle, which means that Si was involved with the formation of root. Some previous researchers assumed that Si mediated-improvement of root system (lateral root formation and growth) was owing to the accumulation of abscisic acid in roots, as a result of the $\mathrm{Si}$ application $[19,20]$. Therefore, it may worth to study if it is true or not via determining abscisic acid in soybean cultivars in the future.

One of the reasons for increasing the growth of soybean cultivars in this study can be to improve the root growth of soybean cultivars. Since a good root system is indispensable for water acquisition and nutrient absorption all over a plant's life [29], it seems the soybean cultivars treated with Si could absorb more water and nutrients and form more nodules on roots (more shoot $\mathrm{N}$ uptake and as a result more growth) compared those not-treated with Si during growth period in the pot experiment. In a previous study, Si application in legumes also increased water uptake [58] probably by increasing root-to-shoot ratio [20]. According to previous studies, $\mathrm{Si}$ also increased nodulation and elongated root length in legumes, as a result, increased the number of infection sites for nodulation by rhizobial strains [24, 28]. Furthermore, the improved root morphological traits associated with Si application was highly correlated with nodulation and shoot dry weight in the present study (data not shown). 
Different growth responses of soybean cultivars to Si application can also be attributed to their root morphological traits (e.g., root dry weight, length, area, and volume) because the root system adjusts plant growth and yield via transporting micro/macronutrients and water. Accordingly, we presume that the improved morphological traits observed in the present study, helped to boosted water or micro/macronutrient uptake from the soil thus, boosting performance would help to augmenting the growth (shoot dry weight) of soybean cultivars.

Our final hypothesis was that Si may increase the activity of soil microorganisms involved in the nutrient cycle, including $\mathrm{Si}$, by improving plant root systems and thus increasing root exudates. In this study, the application of $\mathrm{Si}$ in soybean cultivars could potentially enhance the positive effects of root system (or root exudates) in improving soil biological properties and as a result nodulation and biological nitrogen fixation (e.g., an increase in shoot $\mathrm{N}$ uptake or shoot dry weight) in the roots of these soybean cultivars. We also observed significant correlations between soil biological properties and nodule score (Fig. 9D and E). In a study, Rangaraj, Gopalu [59] reported the positive effect of Si from various sources on beneficial soil microbial population including phosphate solubilizing bacteria, nitrogen fixing bacteria, silicate solubilizing bacteria as well as microbial biomass carbon and nitrogen in the rhizosphere of maize plant. Beneficial soil bacteria, which are considered as plant growth-promoting bacteria, control the chemical and biological properties of soil by absorbing monosilicic acid from soil solution. On the other hand, silicate-solubilizing bacteria (e.g., by releasing $\mathrm{Si}$ in available form to plant) also help soil fertility for better plant growth and other microbes by converting silicate forms to available forms for the plant $[60,61]$.

\section{Conclusions}

According to our results, soil biological properties, shoot, root morphology (e.g., nodulation), and shoot $\mathrm{N}$ uptake of soybean cultivars were changed by application of different Si levels. It was also found that high concentration of $\mathrm{Si}\left(800 \mathrm{mg} \mathrm{kg}^{-1}\right)$ had an inhibitory effect on the growth of soybean cultivars and possibly other legumes. Our findings also suggested that optimal concentrations of Si could be a promising way to improve the production of soybean cultivars by multiple mechanisms such as improvement of nodulation (an increase in $\mathrm{N}_{2}$ fixation), root system architecture (e.g., by the water and mineral uptake from the soil and provision of sites for colonization by bradyrhizobial strains), and soil biological properties (e.g., improved soil fertility), thereby positively affecting the soybean growth. However, current results cannot prove the exact mechanism. To identify concrete evidence related to Si effects on nodulation and as a result the improvement of the growth of soybean cultivars, genetic researches such as an RNA-seq are needed. However, based on the results of this study, the development of fertilizers based on $\mathrm{Si}$ is a very interesting support for the improvement of growth and nitrogen fixation (an increase in shoot $\mathrm{N}$ uptake) in soybean cultivars in the future.

\section{Declarations}


Compliance with Ethical Standards: Not applicable.

Disclosure of potential conflicts of interest: Not applicable.

Research involving Human Participants and/or Animals: Not applicable.

Consent to Participate: Not applicable.

Data Availability: Excel data for measurements is available.

Conflict of interest: Authors declare no conflict of interest.

Funding: This research did not receive any specific grant from funding agencies in the public, commercial, or not-for-profit sectors.

Authors' contributions: All authors have contributed equally to this study. Acknowledgements: We express our gratitude to the University of Tehran for providing the facilities necessary for this research.

Conflict of data and material: The authors declare that they have no conflict of interest.

Consent for Publication: In accordance with the copyright transfer or open access rules.

\section{References}

1. Epstein, E., Silicon. Annual review of plant biology, 1999. 50(1): p. 641-664.

2. Etesami, H., B.R. Jeong, and M. Rizwan, The Use of Silicon in Stressed Agriculture Management: Action Mechanisms and Future Prospects. Metalloids in Plants: Advances and Future Prospects, 2020: p. 381-431.

3. Etesami, H. and B.R. Jeong, Silicon (Si): Review and future prospects on the action mechanisms in alleviating biotic and abiotic stresses in plants. Ecotoxicology and environmental safety, 2018. 147: p. 881-896.

4. Luyckx, M., et al., Silicon and plants: current knowledge and technological perspectives. Frontiers in Plant Science, 2017. 8: p. 411.

5. Ma, J.F. and N. Yamaji, A cooperative system of silicon transport in plants. Trends in Plant Science, 2015. 20(7): p. 435-442.

6. Ouellette, S., et al., Silicon transporters and effects of silicon amendments in strawberry under high tunnel and field conditions. Frontiers in plant science, 2017. 8: p. 949.

7. Putra, R., et al., Is it time to include legumes in plant silicon research? Functional Ecology, 2020. 34(6): p. 1142-1157. 
8. Bellaloui, N., et al., Effects of foliar boron application on seed composition, cell wall boron, and seed $\delta 15 \mathrm{~N}$ and $\delta 13 \mathrm{C}$ isotopes in water-stressed soybean plants. Frontiers in Plant Science, 2013. 4: p. 270.

9. Tripathi, P., C.-I. Na, and Y. Kim, Effect of silicon fertilizer treatment on nodule formation and yield in soybean (Glycine max L.). European Journal of Agronomy, 2021. 122: p. 126172.

10. Zhang, W., et al., Beneficial effects of silicon on abiotic stress tolerance in legumes. Journal of Plant Nutrition, 2017. 40(15): p. 2224-2236.

11. Farhangi-Abriz, S. and S. Torabian, Nano-silicon alters antioxidant activities of soybean seedlings under salt toxicity. Protoplasma, 2018. 255(3): p. 953-962.

12. Rasoolizadeh, A., et al., Silicon protects soybean plants against Phytophthora sojae by interfering with effector-receptor expression. BMC plant biology, 2018. 18(1): p. 1-13.

13. Mansouri Gandomani, V. and H. Omidi, The effect of nano-particle silicon dioxide (SiO2) on improving soybean seed germination under Accelerated aging conditions. Iranian Journal of Seed Science and Technology, 2017. 6(1): p. 193-203.

14. Pereira Junior, P., et al., Effects of doses of silicon in the yield and agronomic characteristics of soybean [Glycine max (L.) Merrill]. Ciência e Agrotecnologia, 2010. 34(4): p. 908-913.

15. Pascual, M.B., et al., Silicon addition to soybean (Glycine max L.) plants alleviate zinc deficiency. Plant Physiology and Biochemistry, 2016. 108: p. 132-138.

16. Etesami, H. and S.M. Adl, Can interaction between silicon and non-rhizobial bacteria benefit in improving nodulation and nitrogen fixation in salinity-stressed legumes? A review. Rhizosphere, 2020: $\mathrm{p}$. 100229.

17. Johnson, S.N., et al., Benefits from Below: Silicon Supplementation Maintains Legume Productivity under Predicted Climate Change Scenarios. Frontiers in Plant Science, 2018. 9(202).

18. Guo, Z.G., et al., Effect of silicon on the morphology of shoots and roots of alfalfa (Medicago sativa). Australian Journal of Experimental Agriculture, 2006. 46(9): p. 1161-1166.

19. Signora, L., et al., ABA plays a central role in mediating the regulatory effects of nitrate on root branching in Arabidopsis. The Plant Journal, 2001. 28(6): p. 655-662.

20. Dakora, F.D. and A. Nelwamondo, Silicon nutrition promotes root growth and tissue mechanical strength in symbiotic cowpea. Functional Plant Biology, 2003. 30(9): p. 947-953.

21. Liang, Y. and J.M. Harris, Response of root branching to abscisic acid is correlated with nodule formation both in legumes and nonlegumes. American Journal of Botany, 2005. 92(10): p. 1675-1683. 
22. Steiner, F., et al., Silicate fertilization potentiates the nodule formation and symbiotic nitrogen fixation in soybean1. Pesquisa Agropecuária Tropical, 2018. 48(3): p. 212-221.

23. Ma, J.F. and N. Yamaji, Silicon uptake and accumulation in higher plants. Trends in plant science, 2006. 11(8): p. 392-397.

24. Nelwamondo, A. and F.D. Dakora, Silicon promotes nodule formation and nodule function in symbiotic cowpea (Vigna unguiculata). New phytologist, 1999. 142(3): p. 463-467.

25. Hu, J., X. Cai, and B.R. Jeong, Silicon affects root development, tissue mineral content, and expression of silicon transporter genes in poinsettia (Euphorbia pulcherrima willd.) cultivars. Plants, 2019. 8(6): p. 180.

26. Deshmukh, R.K., et al., Identification and functional characterization of silicon transporters in soybean using comparative genomics of major intrinsic proteins in Arabidopsis and rice. Plant molecular biology, 2013. 83(4-5): p. 303-315.

27. Arsenault-Labrecque, G., J.G. Menzies, and R.R. Bélanger, Effect of silicon absorption on soybean resistance to Phakopsora pachyrhizi in different cultivars. Plant Disease, 2012. 96(1): p. 37-42.

28. Chung, Y.S., et al., Image-Based Machine Learning Characterizes Root Nodule in Soybean Exposed to Silicon. Frontiers in plant science, 2020. 11.

29. Zhao, J., et al., Root architecture simulation improves the inference from seedling root phenotyping towards mature root systems. Journal of experimental botany, 2017. 68(5): p. 965-982.

30. Waines, J.G. and B. Ehdaie, Domestication and crop physiology: roots of green-revolution wheat. Annals of botany, 2007. 100(5): p. 991-998.

31. Etesami, H., H.A. Alikhani, and H.M. Hosseini, Indole-3-acetic acid and 1-aminocyclopropane-1carboxylate deaminase: bacterial traits required in rhizosphere, rhizoplane and/or endophytic competence by beneficial bacteria, in Bacterial metabolites in sustainable agroecosystem. 2015, Springer. p. 183-258.

32. Etesami, H. and S.M. Adl, Plant growth-promoting rhizobacteria (PGPR) and their action mechanisms in availability of nutrients to plants, in Phyto-Microbiome in Stress Regulation. 2020, Springer. p. 147-203.

33. Rezakhani, L., et al., Effect of Silicon and Phosphate-Solubilizing Bacteria on Improved Phosphorus (P) Uptake Is Not Specific to Insoluble P-Fertilized Sorghum (Sorghum bicolor L.) Plants. Journal of Plant Growth Regulation, 2020. 39(1): p. 239-253.

34. Bahari, S.S., H. Pirdashti, and Y. Yaghoubian, The effects of nitrogen and silicon biofertilizers on powdery mildew disease, physiological parameters and yield of wheat (Triticum aestivum L.). 2012. 
35. Rezakhani, L., et al., Phosphate-solubilizing bacteria and silicon synergistically augment phosphorus $(P)$ uptake by wheat (Triticum aestivum L.) plant fertilized with soluble or insoluble $P$ source. Ecotoxicology and Environmental Safety, 2019. 173: p. 504-513.

36. Corbin, E.J., J. Brockwell, and R.R. Gault, Nodulation studies on chickpea (Cicer arietinum). Australian Journal of Experimental Agriculture, 1977. 17(84): p. 126-134.

37. Swift, R.S., Organic matter characterization. Methods of soil analysis: Part 3 chemical methods, 1996. 5: p. 1011-1069.

38. Hallmark, C.T., L.P. Wilding, and N.E. Smeck, Silicon. Methods of Soil Analysis: Part 2 Chemical and Microbiological Properties, 1983. 9: p. 263-273.

39. Vance, E.D., P.C. Brookes, and D.S. Jenkinson, An extraction method for measuring soil microbial biomass C. Soil biology and Biochemistry, 1987. 19(6): p. 703-707.

40. Isermeyer, H., Estimation of soil respiration in closed jars. Method in applied soil microbiology and biochemistry. Academy, London, 1952: p. 214-216.

41. Tan, S., R.B. Maxcy, and W.W. Stroup, Colony-forming unit enumeration by a plate-MPN method. Journal of food protection, 1983. 46(10): p. 836-841.

42. Kang, S.-M., et al., Isolation and characterization of a novel silicate-solubilizing bacterial strain Burkholderia eburnea CS4-2 that promotes growth of japonica rice (Oryza sativa L. cv. Dongjin). Soil Science and Plant Nutrition, 2017. 63(3): p. 233-241.

43. Mali, M., Aery, and C. Naresh, Silicon effects on nodule growth, dry-matter production, and mineral nutrition of cowpea (Vigna unguiculata). Journal of Plant Nutrition and Soil Science, 2008. 171(6): p. 835-840.

44. Hodson, M.J., et al., Phylogenetic variation in the silicon composition of plants. Annals of botany, 2005. 96(6): p. 1027-1046.

45. Epstein, E., The anomaly of silicon in plant biology. Proceedings of the National Academy of Sciences, 1994. 91(1): p. 11-17.

46. Nascimento, K.J.T., et al., Soybean resistance to Cercospora sojina infection is reduced by silicon. Phytopathology, 2014. 104(11): p. 1183-1191.

47. Miyake, Y. and E. Takahashi, Effect of silicon on the growth of soybean plants in a solution culture. Soil science and plant nutrition, 1985. 31(4): p. 625-636.

48. Nelwamondo, A., M.A. Jaffer, and F.D. Dakora, Subcellular organization of N 2-fixing nodules of cowpea (Vigna unguiculata) supplied with silicon. Protoplasma, 2001. 216(1-2): p. 94. 
49. Johnson, S.N., et al., Silicon-induced root nodulation and synthesis of essential amino acids in a legume is associated with higher herbivore abundance. Functional Ecology, 2017. 31(10): p. 1903-1909.

50. Garg, N. and S. Singh, Arbuscular mycorrhiza Rhizophagus irregularis and silicon modulate growth, proline biosynthesis and yield in Cajanus cajan L. Millsp. (pigeonpea) genotypes under cadmium and zinc stress. Journal of plant growth regulation, 2018. 37(1): p. 46-63.

51. Zhang, G., et al., Stimulation of phenolic metabolism by silicon contributes to rice resistance to sheath blight. Journal of plant nutrition and soil science, 2013. 176(1): p. 118-124.

52. Van Bockhaven, J., D. De Vleesschauwer, and M. Höfte, Towards establishing broad-spectrum disease resistance in plants: silicon leads the way. Journal of experimental botany, 2013. 64(5): p. 12811293.

53. Eckardt, N.A., The role of flavonoids in root nodule development and auxin transport in Medicago truncatula. 2006, Am Soc Plant Biol.

54. Ott, T., et al., Symbiotic leghemoglobins are crucial for nitrogen fixation in legume root nodules but not for general plant growth and development. Current biology, 2005. 15(6): p. 531-535.

55. Hardarson, G. and S.K.A. Danso, Methods for measuring biological nitrogen fixation in grain legumes. Plant and soil, 1993. 152(1): p. 19-23.

56. Sulieman, S. and L.-S.P. Tran, Symbiotic nitrogen fixation in legume nodules: metabolism and regulatory mechanisms. 2014, Multidisciplinary Digital Publishing Institute.

57. Neu, S., J. Schaller, and E.G. Dudel, Silicon availability modifies nutrient use efficiency and content, C: N: P stoichiometry, and productivity of winter wheat (Triticum aestivum L.). Scientific Reports, 2017. 7(1): p. 1-8.

58. Chen, D., et al., How does silicon mediate plant water uptake and loss under water deficiency? Frontiers in plant science, 2018. 9: p. 281.

59. Rangaraj, S., et al., Effect of silica nanoparticles on microbial biomass and silica availability in maize rhizosphere. Biotechnology and applied biochemistry, 2014. 61(6): p. 668-675.

60. Theng, B.K.G. and G. Yuan, Nanoparticles in the soil environment. Elements, 2008. 4(6): p. 395399.

61. Nanayakkara, U.N., W. Uddin, and L.E. Datnoff, Application of silicon sources increases silicon accumulation in perennial ryegrass turf on two soil types. Plant and soil, 2008. 303(1): p. 83-94.

\section{Figures}




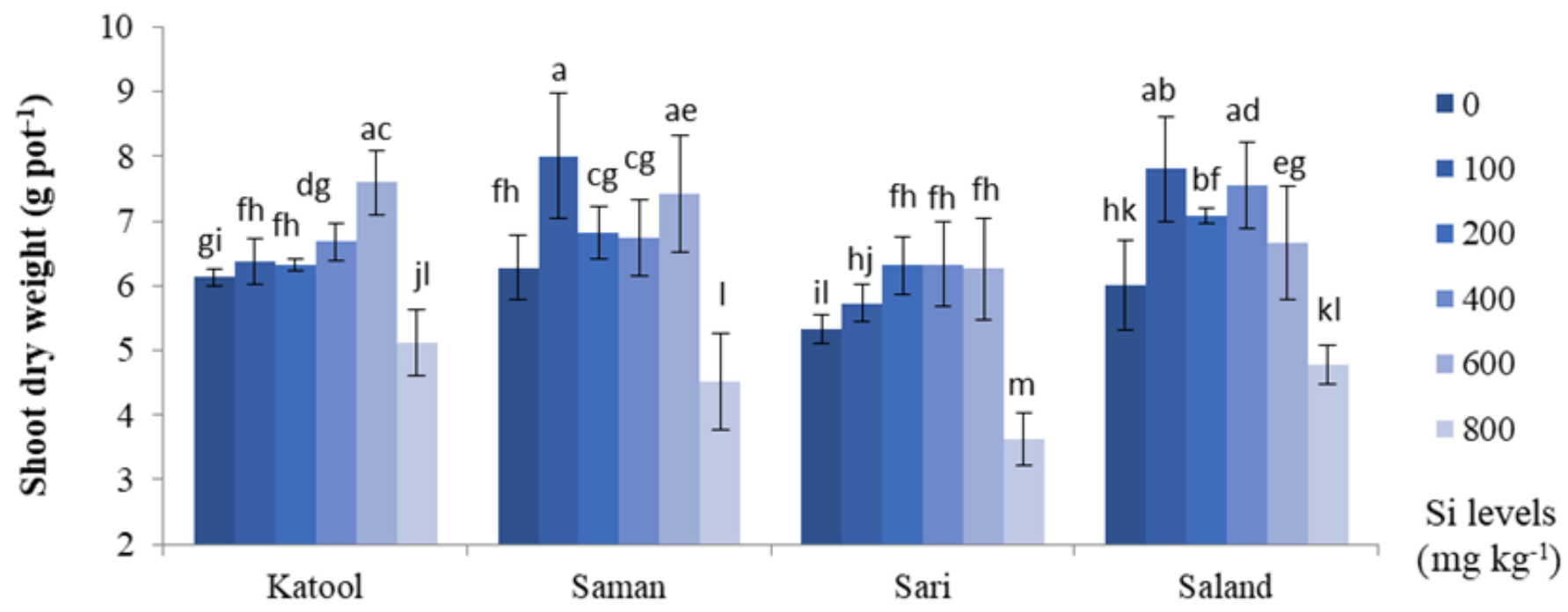

Soybean cultivars

Figure 1

Effect of silicon ( $\mathrm{Si}$ ) levels on shoot dry weight of four soybean cultivars under greenhouse conditions. Means $\pm S D(n=3)$ followed by the same letters in Fig. 1A are not significantly different according to Tukey's multiple range test at $\mathrm{P}<0.05$.

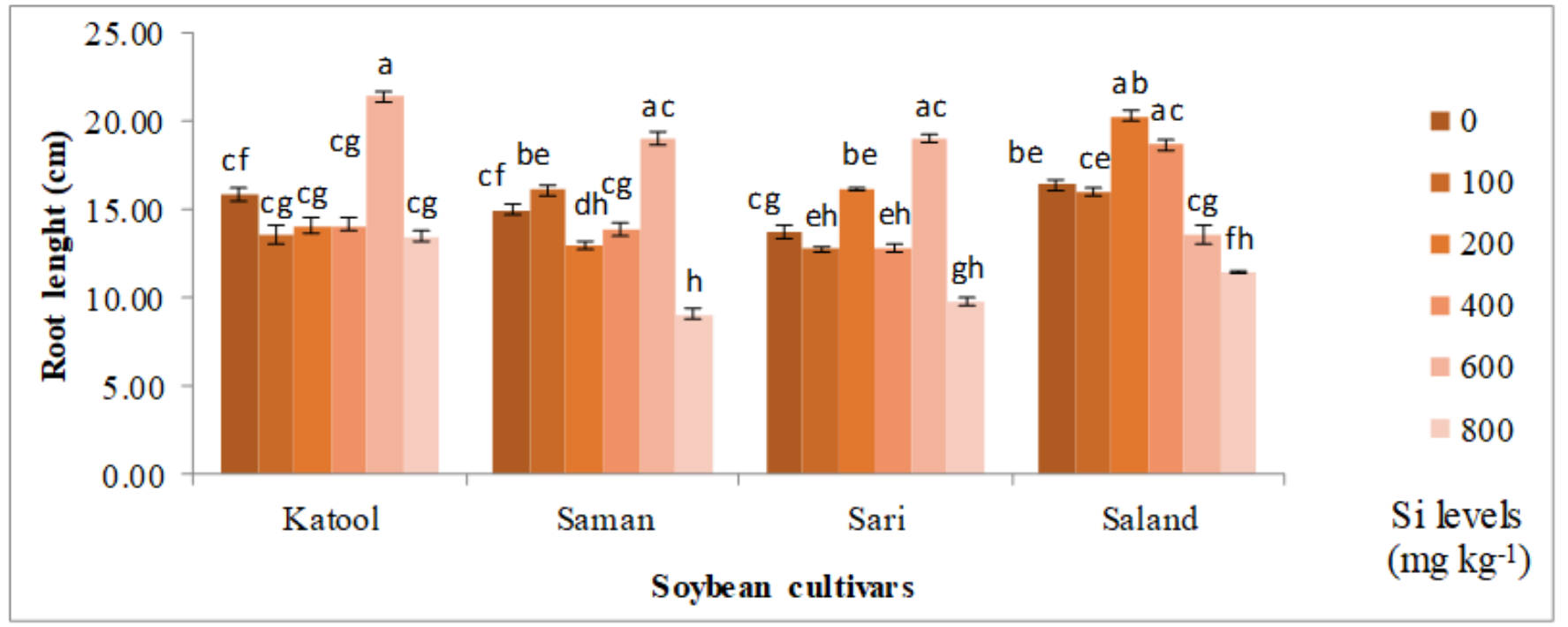

Figure 2

Effect of silicon ( $\mathrm{Si}$ ) levels on root length of four soybean cultivars under greenhouse conditions. Means \pm SD $(n=3)$ followed by the same letters in Fig. $1 \mathrm{~A}$ are not significantly different according to Tukey's multiple range test at $\mathrm{P}<0.05$. 


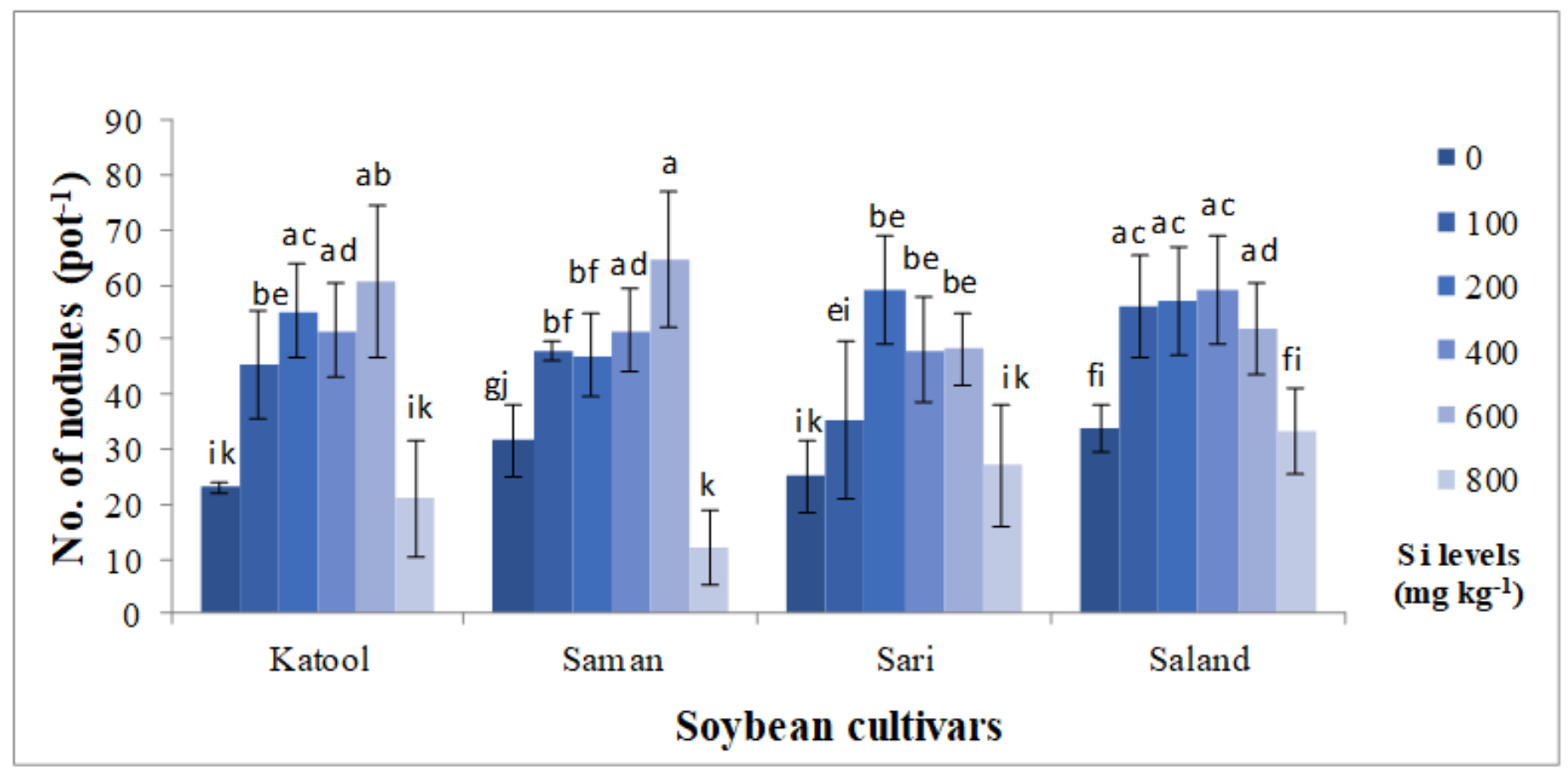

\section{Figure 3}

Effect of silicon (Si) levels on number of nodules of four soybean cultivars under greenhouse conditions. Means $\pm S D(n=3)$ followed by the same letters in Fig. 1A are not significantly different according to Tukey's multiple range test at $\mathrm{P}<0.05$.

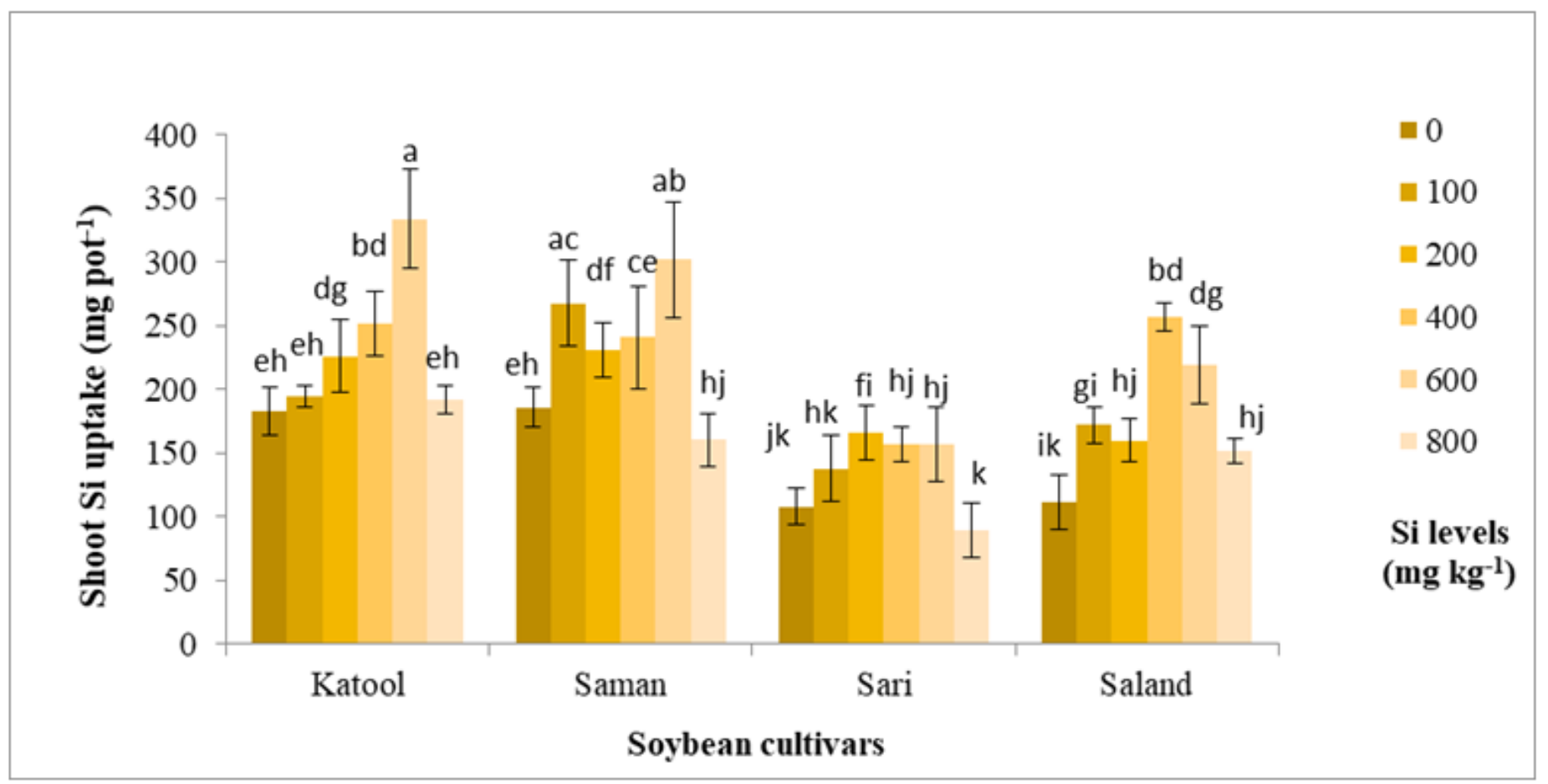

Figure 4 
Effect of silicon (Si) levels on shoot silicon (Si) uptake of four soybean cultivars under greenhouse conditions. Means $\pm S D(n=3)$ followed by the same letters in Fig. 1A are not significantly different according to Tukey's multiple range test at $\mathrm{P}<0.05$.

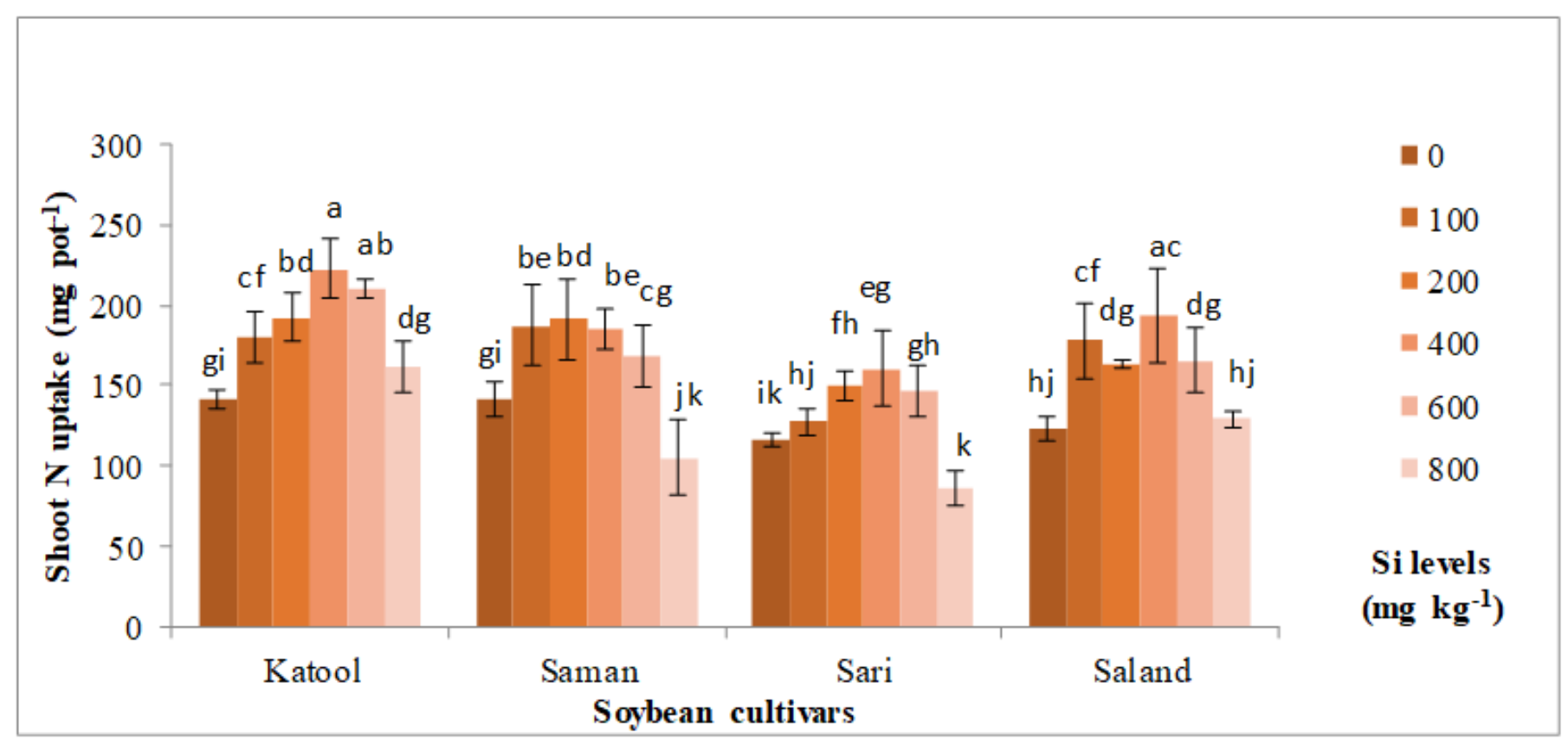

Figure 5

Effect of silicon $(\mathrm{Si})$ levels on shoot nitrogen $(\mathrm{N})$ uptake of four soybean cultivars under greenhouse conditions. Means $\pm S D(n=3)$ followed by the same letters in Fig. 1A are not significantly different according to Tukey's multiple range test at $\mathrm{P}<0.05$. 


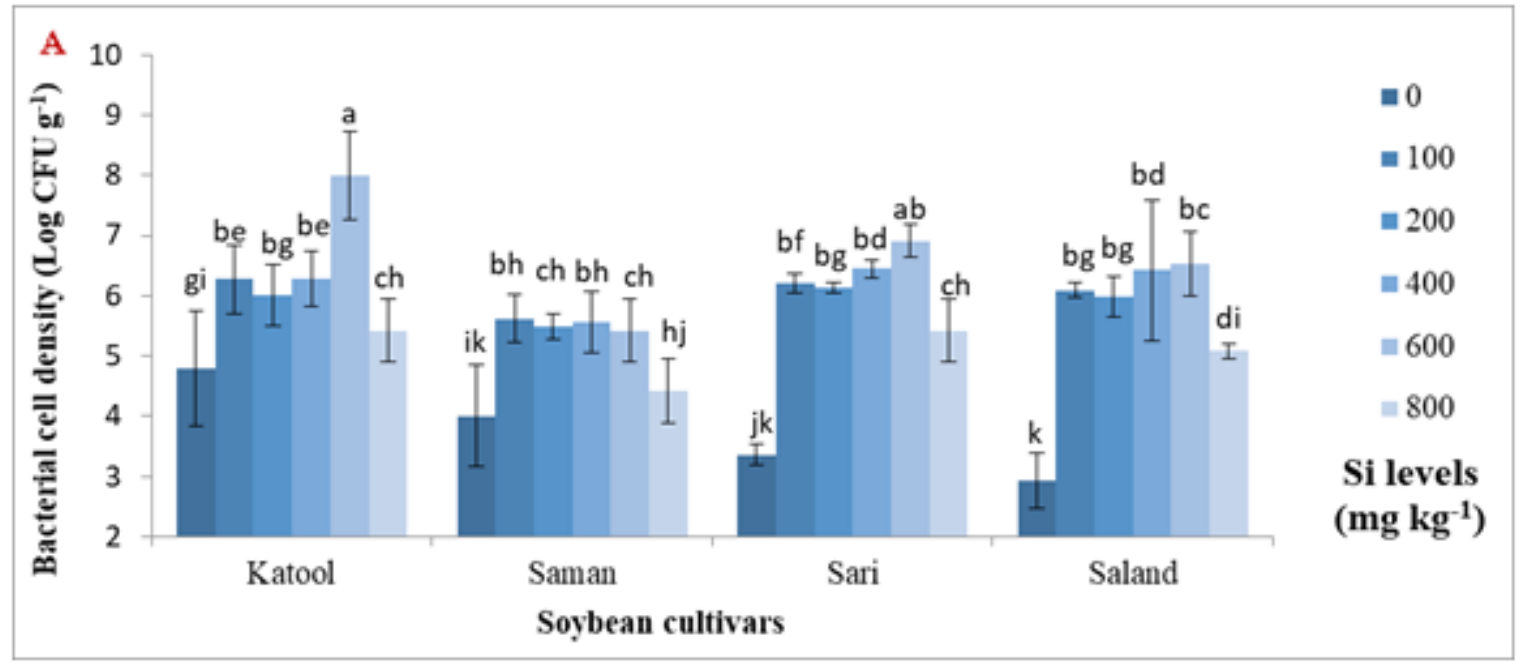

B

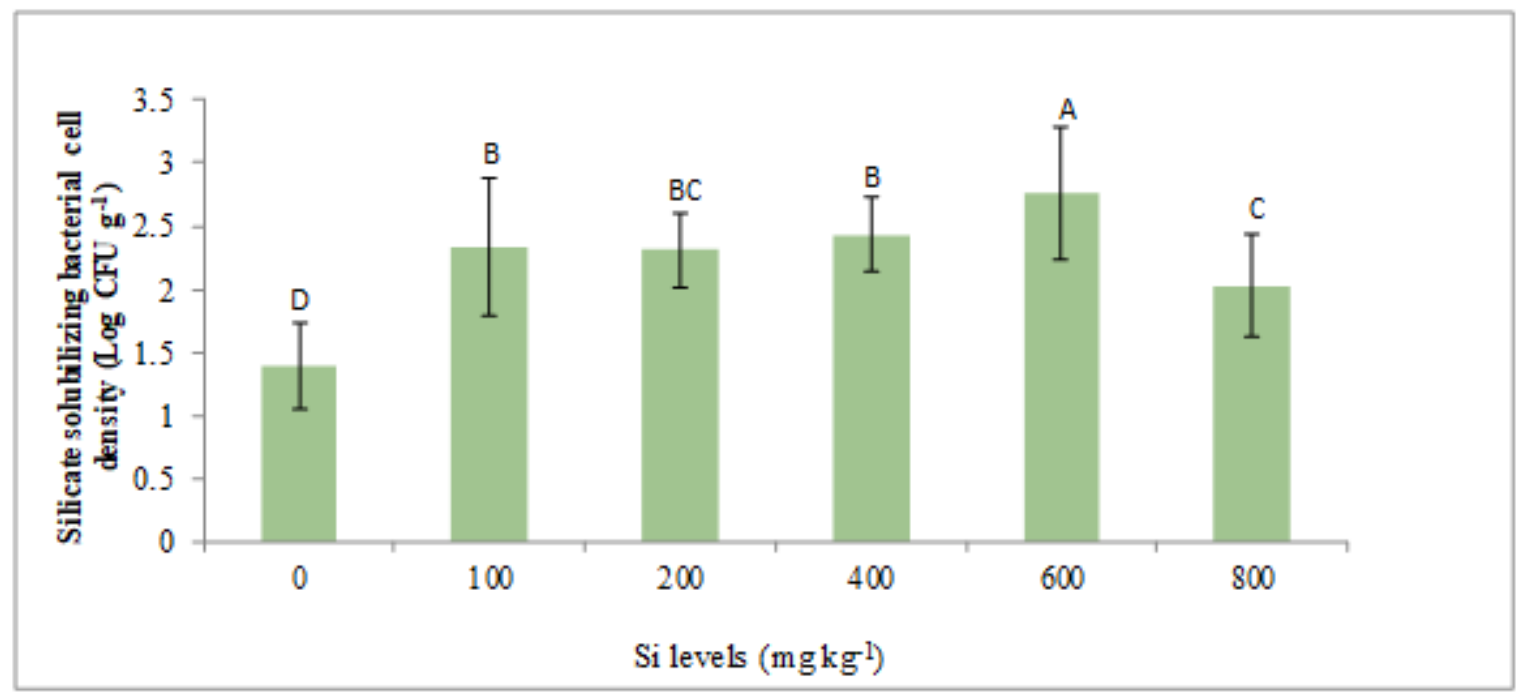

Figure 6

(A), effect of silicon ( $\mathrm{Si}$ ) levels on the total bacterial cell density of soil under cultivation of four soybean cultivars and (B), effect of silicon (Si) levels on soil silicate solubilizing bacterial cell density under greenhouse conditions. Means $\pm S D(n=3)$ followed by the same letters in Fig. 1A are not significantly different according to Tukey's multiple range test at $P<0.05$. 

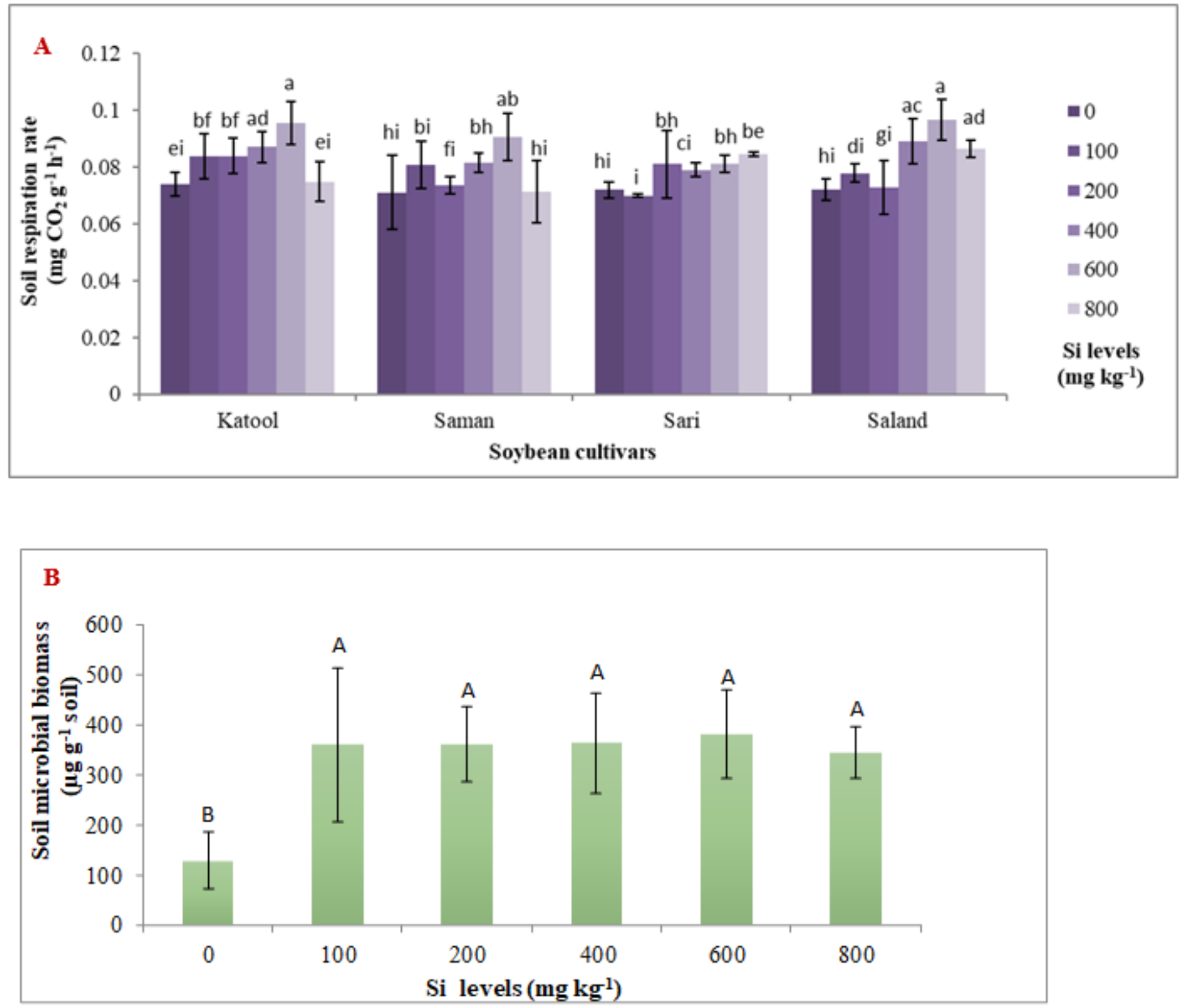

Figure 7

(A), effect of silicon (Si) levels on microbial respiration rate of soil under cultivation of four soybean cultivars and (B), effect of silicon (Si) levels on soil microbial biomass under greenhouse conditions. Means $\pm S D(n=3)$ followed by the same letters in Fig. 1A are not significantly different according to Tukey's multiple range test at $\mathrm{P}<0.05$. 

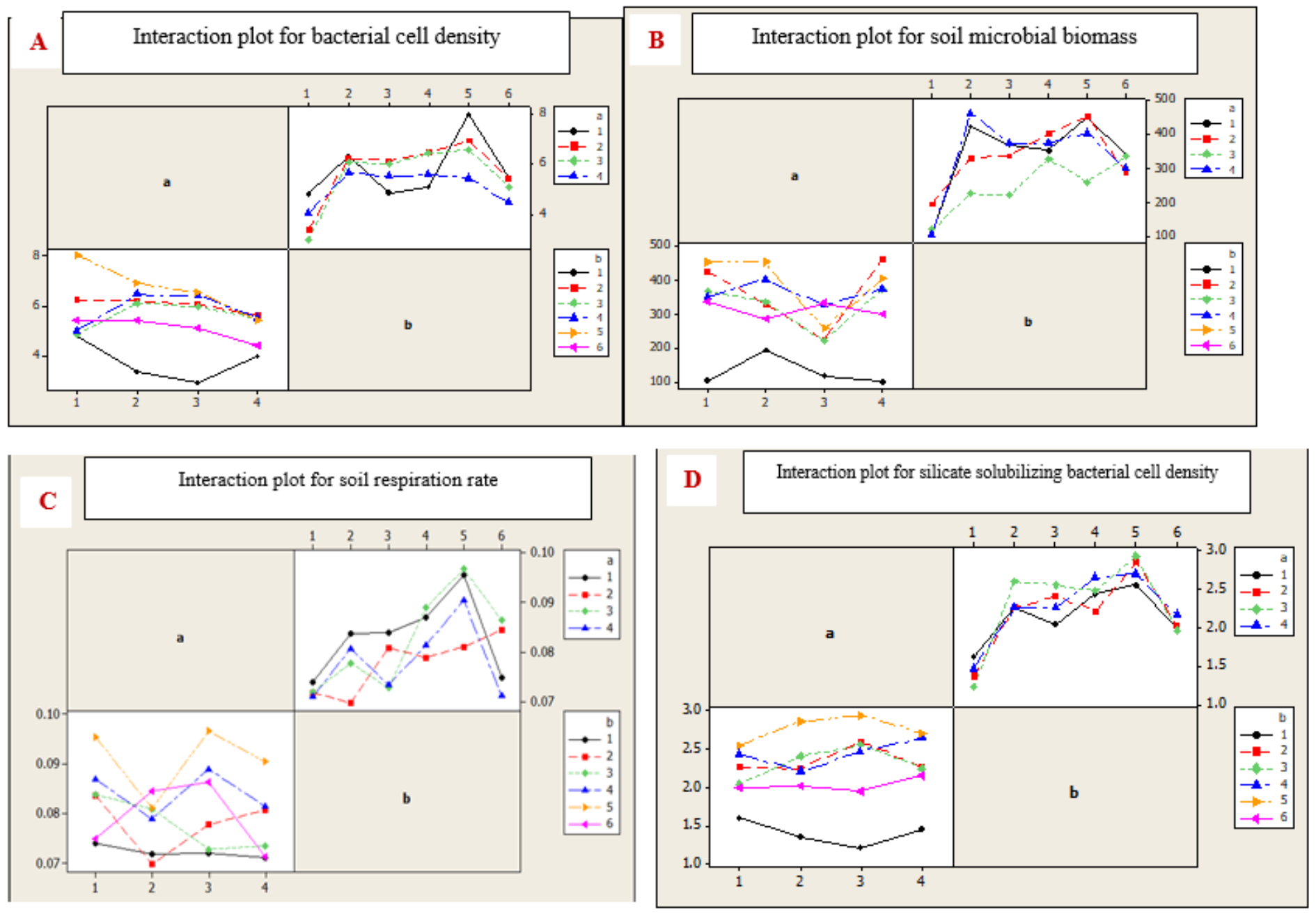

\section{Figure 8}

Interaction plot for bacterial cell density (A), for soil microbial biomass (B), for soil respiration rate (C), and for silicate solubilizing bacterial cell density (D). In these graphs ( $a$ and $b$ ), the numbers 1 to 6 on the horizontal axis indicate the levels of silicon (respectively, 0, 100, 200, 400, 600, and $800 \mathrm{mg} \mathrm{Si} \mathrm{kg-1)}$ ) and the numbers 1 to 4 , each marked with a color, indicate the soybean cultivars (respectively, Katool, Sari, Saland and Saman). The intersection of the lines with each other shows that the interactions are significant. If the lines are parallel, the interactions of silicon on the cultivars are not significant $(P<0.05)$. 

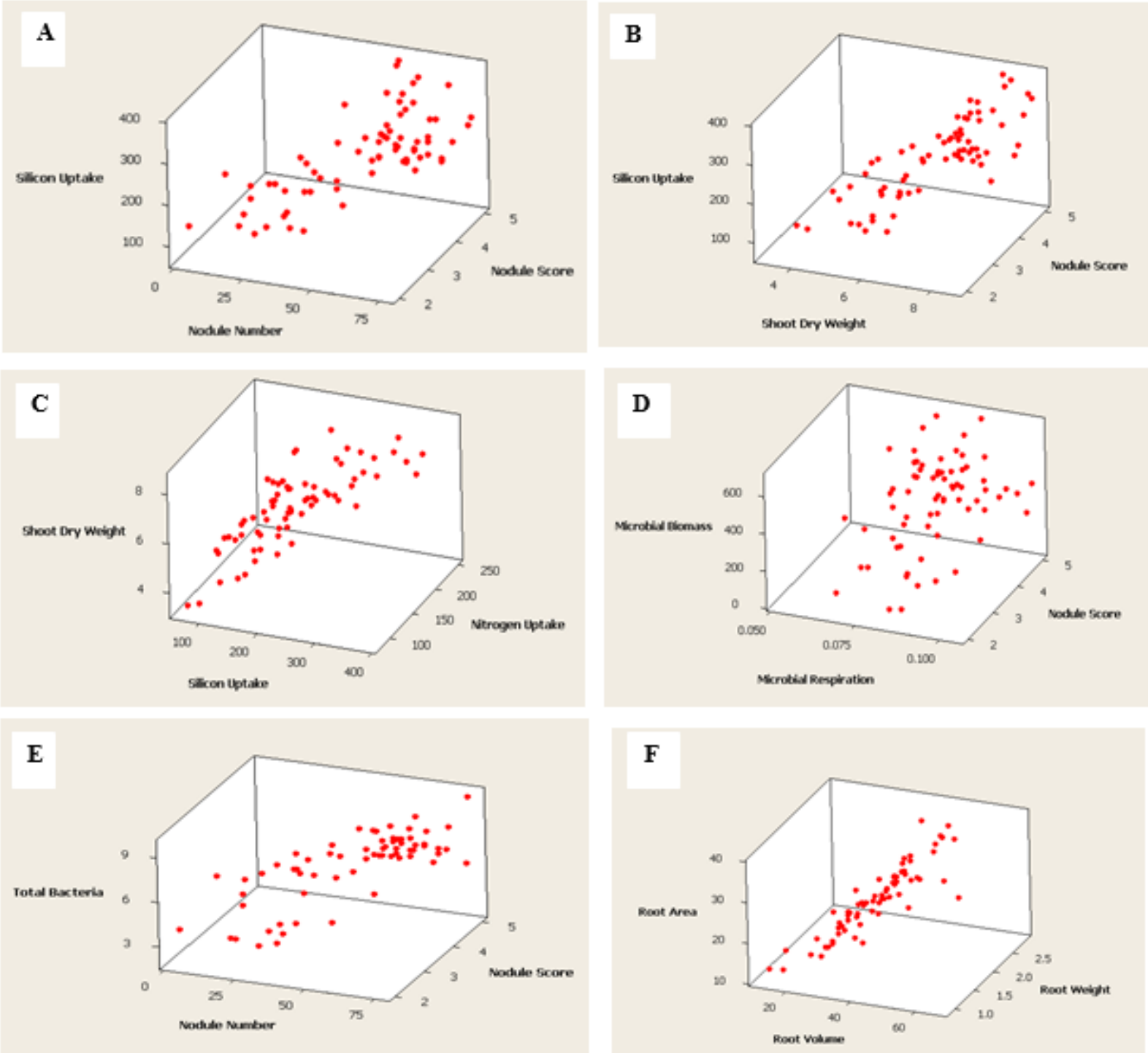

Figure 9

The three-dimensional graph the relationships among some of the measured parameters 